\title{
Study on Psychology of Audience Luxury Brand Clothing in Online Shopping
}

\author{
Yuemei Gao ${ }^{1, \text { a }}$, Weiqi $\mathrm{Li}^{2, \mathrm{~b}}$ \\ ${ }^{1}$ Jiangxi Science \& Technology Normal University, Art College, Nanchang, Jiangxi, 330013 \\ ${ }^{2}$ Beijing Institute of Fashion Technology, School of Art and Engineering, Beijing, 100029 \\ a email, ${ }^{b}$ email
}

Keywords: Online Shopping, Clothing, Luxury Brands, Audience Psychology

\begin{abstract}
As China's economy continues to develop, people's living standards have improved, the material life demands more and more people prefer to buy clothing of luxury brands, so as to promote China to become a luxury consumer. At the same time the economic development also contributed to the progress of science and technology, nowadays, the Internet has become increasingly common, most people choose to shop online rather than go out shopping, so that the net purchase of luxury clothing brand was more widespread. In response to this phenomenon, this paper based on the psychological development of online shopping and the general public to buy online luxury clothing brands to study and make recommendations on the net purchase of luxury clothing brand.
\end{abstract}

\section{Introduction}

On the one hand, due to the continuous economic development, improve people's economic level, no matter, so the purchasing power of people has continued to rise, resulting in domestic demand for luxury brands growing on this trend, China's introduction of foreign luxury brands. Meanwhile, with the continuous development of science and technology, e-commerce market is becoming more fiery, more and more consumers are biased in favor of online shopping. On the other hand, with the shift of consumers to purchase, many goods are also for online sales, including many luxury. Because some level of development of the city is not enough, some luxury brands do not have their own stores, so I chose to transfer goods to the shop, make online shopping more varieties of goods, but also because the shop do not like the store to pay the same rent, utilities and other expenses, the net purchase of commodity prices will be lower than the line of goods, from more to stimulate consumer desire to buy online.

\section{Online Shopping}

Online shopping means consumers want to buy on the Internet search product information, and online ordering of goods through electronic and fill in the relevant payment information, the seller after receiving the purchase information sent by courier to select merchandise. With the development of the country online shopping also formulated relevant laws "Network transaction management approach", "acts against the interests of consumers penalties" and other series of laws to protect the legitimate rights and interests of consumers buy online goods are not infringed.

With the popularity of Internet use at home, online shopping gradually into the consumer's life. Then more and more shopping sites such as Dangdang, Taobao, Amazon, the only product, Jingdong Mall and other shopping sites, continue to impact the Chinese market today, people can not go out shopping, at home, you can buy goods. Then the state of the Internet to promote the advantages of online shopping is more obvious, people gradually become a major way of shopping.

Online shopping is mainly consumers through the process of buying goods on the Internet, is among the main features of buyers and sellers do not need to meet, just look on the net commodity-related information, in transactions over the network.

Product sales through the Internet, sellers do not need to look for the shop, do not pay utility bills 
and property management fees, the seller only need to bear the cost of logistics, reduced operating costs sellers fundamentally.

Online product information will be more comprehensive, relevant information about the seller will be marked on the product page, just point the consumer will be able to open links to product information at a glance.

Consumers can not go out to buy goods for consumers to save time and effort,

\section{Luxury Clothing Brand}

Due to the rapid development of online shopping, many consumers online shopping soft spot, November 11, 2015, Taobao "Lynx double eleven" turnover reached 91.217 billion, the highest point in the history of online shopping into, with the improvement of people's living standards . Consumers in the online shopping goods requirements gradually increase, from low-end to buy cheap goods to buy expensive high-end merchandise, from clothing, household goods to skin care cosmetics, jewelery, watches and other luxury goods.

China's vast territory, large population, a majority of high-end luxury apparel brands are trying to enter China market, at a certain level of impact of the traditional consumer concept of consumption. However, the level of China's economy has been greatly improved our consumer high-end luxury apparel brands, but the capacity is limited, and the domestic high-end luxury store rents, though there are many currently do not offer any luxury brand outlets, these phenomena indicate luxury online sales will bring greater opportunities in China sales network development.

Whether you open the shopping site can see the various categories of goods, such as clothing from around the world, cosmetics, electronic products, food and other daily necessities category, online sales array of goods.

Luxury with a noble characteristic, with the improvement of people's living standards, more and more people on the clothing requirements increase, I want to be able to enhance the status and civilians gap, a surge of wind comparisons, this is exactly the luxury brand apparel can achieve the characteristics of a consumer demand. Due to the net purchase price of luxury brand clothing outlets low price about $20 \%$ higher than in, and a wide range of luxury brands online, consumers are more willing to buy online luxury clothing brand, to achieve the double benefit purposes.

Although the rapid development of China's economic level, but the domestic cities are not fully keep up with the pace of economic development, most of the luxury brand clothing outlets concentrated in the "north-Canton" and other first-tier cities, luxury apparel brand in other cities, according to their level of urban development to run, so in some of the city economy is relatively backward, the luxury brand clothing species decreases. But consumer demand for luxury clothing brand has not declined, so many consumers choose to buy online like luxury.

In particular, 80, 90, after the main force of the Internet users, online shopping also occupies the top position. Celebrity aristocracy is strong buyers of luxury clothing, a relatively small crowd of celebrities nobility, luxury clothing brands to expand consumer groups point to the target 80, 90 white-collar workers, according to what they want to show off their consumer psychology, luxury brand clothing appropriate price reduction to meet consumer demand for white-collar, white-collar workers at the overdraft salary to buy a luxury brand clothing, with a minimum price of luxury goods to meet their own hearts pursuit.

\section{The Introductions of Luxury Brands in Network Clothing and Consumers}

Clothing online shopping with economic development, people's living standards improve, scientific and technological progress, improving consumer material lifestyle, luxury brand clothing online shopping is increasingly common, this paper will provide advice for the above phenomenon online luxury brand apparel business and consumer perception .

Online shopping platform to follow the pace of the times, pay attention to the consumer online shopping experience luxury brand clothing. Different customer demand for open commodity intelligent search for keywords you want to change in real time; try to open mode, so that 
consumers can see on the Internet the effect of wearing apparel; attract the attention of potential customers, to open a floating pop-up ads related to this brand to attract the attention of consumers, increase the purchase rate.

Use the micro-blog, blog and other social networking software to allow other users to click send dynamic dynamic to increase traffic to the promotion of goods; allow for the use of blog post, enhance brand reputation ENDORSEMENTS star; and in the luxury brand clothing outlets Like online shop open membership, such preferential bigger to meet the psychological needs of target customers.

Online sales are diversified sales mode, you need to manage the sales process ,, luxury brand sales not only do graphic design, photography, video and other works exhibition for luxury brands to increase coverage, in terms of sales for luxury goods, each a link will need skill, both to reflect the noble taste, but also relatively friendly price.

Consumers choose online shopping luxury brand apparel mainly online luxury brand clothing prices relative to the lower price outlets, discount forceful, variety. But some consumers are overdraft consumption, this consumption is not worth promoting. For consumers, to establish a correct concept of consumption:

Live within our means, appropriate consumption, consumers should combine their actual net purchases of luxury clothing, avoid buying them

Do not follow suit, rational purchase, according to their need to buy what kind of clothing, not because someone else to buy, you can buy followers, when consumption have their own minds.

Consumers want to own a certain economic base and then choose to buy luxury brands.

Net purchase luxury brand clothing should be selected when buying the business activities can not only save money, but also enhance the consumer clothing goods.

In short, with the continuous economic development, with the emergence of new technologies, online shopping has become one of consumer buying patterns. Economic development requirements encourage consumers to improve the material life, increase consumer spending levels, more and more consumers purchase luxury brand clothing, but because the economy is limited, many consumers choose online shopping luxury brand clothing. This paper is based on the net purchase of luxury clothing brand audience psychological study recommended that consumers buy clothing online luxury brands need to combine their purchasing power.

\section{Acknowledgements}

Jiangxi Science \& Technology Normal University Dr. Research Fund Project "Film Industry in China since the Reform and Opening and Countermeasures."

Fund projects or topics: 15324 Research Program - College fashion show teaching practice management software development.

\section{References}

[1] Cheng Mingyue. On the background of the new economic era of luxury clothing brand marketing strategy [D]. Hunan Normal University, 2012.

[2] Fei Tao. Motivation and Types of [D]. network platform luxury consumers buy clothing. Donghua University, 2014.

[3] Ge Dawei. Luxury brands with fashion magazine brand communication mode of interpretation [D]. Guangxi University, 2013.

[4] Chen Jie. Luxury network of integrated marketing application of [D]. in the Chinese market. Shanghai International Studies University, 2014. 